\title{
PENILAIAN KESEHATAN KJKS BMT BINAMAS
}

\author{
Adi Angga Sukmana \\ KAP Heliantono \\ Email: adianggas@gmail.com \\ Sri Mulyati \\ Program Studi Akuntansi Syariah \\ Sekolah Tinggi Ekonomi Islam SEBI
}

\begin{abstract}
The analysis conducted will interpret ratios or financial data and its implications. This research is compiled to analyze health assessment KJKS BMT Binamas years 20122014 using a standard assessment of the Regulation of the Minister of State for Cooperatives and SMEs RI Number: 35.3 / Per / M.KUKM / X / 2007 on guidelines for a health assessment KJKS and UJKS Cooperative. The results of this study will be taken into consideration in the evaluation and a policy for BMT KJKS Binamas to improve their business performance so that stability is maintained and is expected to enhance public trust in this Islamic Microfinance Institutions. The approach used in this study is a quantitative and descriptive variables used are capital; asset quality; management; efficiency; liquidity; independence and growth; the identity of the cooperative; and compliance with Islamic principles. Based on analysis of the health assessment KJKS BMT Binamas can be seen that score recapitulation of eight variables in 2012 amounted to $74.92 \%$ so that it can be categorized fairly sound, and in 2013 increased to $74.92 \%$ with the category Fairly Healthy, later in 2014 slightly decreased to $75.95 \%$ are still in the category of Fit. Value ratios consistently rated high happens because KJKS continue to maintain sound operational.
\end{abstract}

Keywords: Health Assessment, Soundness, Cooperative Sharia, KJKS, BMT.

\section{PENDAHULUAN}

Persaingan dalam bidang ekonomi semakin lama cenderung semakin ketat di era globalisasi kekinian. Oleh karena itu, setiap perubahan yang terjadi harus diperhitungkan dan diantisipasi. Demikian halnya dengan para pelaku ekonomi khususnya koperasi, terutama terhadap kinerja keuangan koperasi yang dituntut untuk cepat tanggap dalam mengambil keputusan untuk mencegah hilangnya peluang keuntungan yang ada atau sebaliknya akan mendatangkan kerugian bagi koperasi. Sehubungan dengan hal itu, koperasi harus lebih tangguh dalam menghadapai perubahan dan persaingan yang terjadi didalam lingkungan koperasi itu sendiri atau bersaing dengan lembaga keuangan bukan bank lainnya, baik secara regional, nasional, maupun internasional (Budiyanto \& Soleh, 2013, hlm.39).

Koperasi Indonesia mempunyai peran sebagai penangkal terhadap kapitalisme, individualisme dan liberalisme. Koperasi merupakan wadah bagi rakyat Indonesia dengan ekonomi lemah, yang mempunyai kepentingan bersama untuk mewujudkan masyarakat makmur, adil, dan merata 
(Netrawati, 2013, hlm.57). Sama halnya dengan koperasi, koperasi syariah atau yang lebih masyarakat kenal dengan BMT (Baitul Maal Wat Tamwil) merupakan lembaga ekonomi masyarakat yang bertujuan untuk mendukung kegiatan usaha ekonomi rakyat bawah dan kecil, yang dijalankan berdasarkan syariat Islam. Dan dalam menghadapi perkembangan ekonomi nasional dan global yang semakin dinamis dan penuh tantangan maka dari itu dibutuhkan koperasi yang sehat dan mandiri (Mudjiyanti \& Rachmawati, 2014, hlm.86).

Peran BMT di Indonesia sangat penting yaitu sebagai perantara (mediator) antara masyarakat yang kelebihan dana dan masyarakat yang kekurangan dana, terutama untuk memberikan pembiayaan kepada usaha mikro dan kecil. Beberapa alasan pangsa pasar BMT adalah usaha mikro dan kecil karena biasanya mereka tidak melakukan catatan akuntansi yang baik, oleh karena itu sulit bagi lembaga perbankan untuk memantau dan mengontrol perkembangan usahanya bahkan sangat berisiko. Tetapi Hal ini mungkinkan bagi BMT untuk melakukan pemantauan langsung dan karena BMT didirikan dalam bentuk komunitas sehingga memiliki hubungan yang baik antar anggotanya (Wardiwiyono, 2012, hlm.342).

Tabel 1 Rekapitulasi Jumlah Koperasi (Unit) dan Aset

\begin{tabular}{cccccc}
\hline \multirow{2}{*}{ Tahun } & \multicolumn{3}{c}{ Jumlah Koperasi (Unit) } & Modal Sendiri (Rp. & $\begin{array}{c}\text { Volume Usaha } \\
\text { (Rp. Juta) }\end{array}$ \\
\cline { 2 - 4 } & Jumlah & Aktif & Non Aktif & Juta) & $105,800,829.73$ \\
\hline 2014 & 209,488 & 147,249 & 62,239 & $189,858,671.87$ \\
\hline 2013 & 203,701 & 143,117 & 60,584 & $89,536,290.61$ & $125,584,976.19$ \\
\hline 2012 & 194,295 & 139,321 & 54,976 & $51,422,621.07$ & $119,182,690.08$ \\
\hline 2011 & 188,181 & 133,666 & 54,515 & $35,794,284.64$ & $95,062,402.21$ \\
\hline 2010 & 177,482 & 124,855 & 52,627 & $30,102,013.90$ & $76,822,082.40$ \\
\hline \multicolumn{5}{c}{ Sumber diolah: Kementerian Koperasi dan Usaha Kecil dan Menengah Tahun 2015 }
\end{tabular}

Sampai akhir 2014 perkembangan koperasi baik dilihat dari jumlah unit maupun jumlah aset koperasi selalu mengalami peningkatan, dimana tahun 2014 Indonesia memiliki 147.249 unit koperasi yang beroprasi aktif dan memiliki aset lebih dari Rp 189.858.671 juta. Secara umum koperasi di Indonesia memang mengalami peningkatan, akan tetapi terlepas dari itu, jumlah koperasi yang tidak aktif beroperasi juga mengalami peningkatan dari tahun ke tahun. Jumlah ini akan semakin bertambah pada masa mendatang seiring dengan perkembangan industri keuangan yang berbasis syariah akhirakhir ini (Kementerian Koperasi, 2014, hlm.25).

Pesatnya perkembangan BMT tidak berarti bahwa lembaga ini terbebas dari serentetan masalah yang menjadi risiko. Beberapa BMT terpaksa harus gulung tikar, bangkrut, tidak beroperasi, dan bahkan harus berhadapan dengan persoalan hukum karena mis-management (Hafidz, Ismanto, \& Rozi, 2011, hlm.2). Faktor yang menyebabkan terjadinya kegagalan BMT, yaitu: pertama, kurangnya persiapan SDM (pengelola) baik pengetahuan maupun keterampilan dalam mengelola BMT terutama dalam pengguliran pembiayaan. Contoh: banyaknya pembiayaan yang tidak tertagih 
(pembiayaan macet) adalah penyebab terbesar dari gagalnya usaha BMT. Kedua, lemahnya pengawasan pengurus pada pengelola terutama dalam manajemen dana, dan juga kurangnya rasa memiliki (peduli) pada BMT (Wardiwiyono, 2012, hlm.341).

Untuk itu, penilaian kesehatan perlu dilakukan pada tiap akhir periode tertentu, dan ini merupakan salah satu tindakan penting yang harus dilakukan oleh koperasi guna mengetahui prestasi dan keuntungan yang dicapainya melalui indikator-indikator pengukuran tingkat kesehatan keuangan dengan harapan koperasi beroperasi secara normal dan mampu memenuhi semua kewajibannya sesuai dengan peraturan yang berlaku (Afandi, 2014, hlm.26).

Sebagian besar BMT berbadan hukum koperasi oleh karena itu BMT tunduk pada UU Nomor: 17 Tahun 2012 tentang Perkoperasian. Penilaian kesehatan BMT dilakukan dengan memperhatikan peraturan kesehatan koperasi yang dikeluarkan oleh Kementerian Negara Koperasi dan UKM Republik Indonesia Nomor: 35.3/Per/M.KUKM/X/2007 tentang Pedoman Pelaksanaan Penilaian Kesehatan Koperasi Jasa Keuangan Syariah dan Unit Jasa Keuangan Syariah Koperasi. Selain karena keharusan bagi lembaga berbadan Koperasi Jasa Keuangan Syariah untuk menilai kesehatannya, akan tetapi hal ini juga karena kedelapan variabel tersebut merupakan variabel dasar untuk mengukur kinerja suatu lembaga keuangan mikro syariah dari delapan aspek dibandingkan dengan metode penilaian lainnya (Ismaya, Susanta \& Rodhiyah, 2014, hlm.2).

KJKS BMT Binamas saat ini memiliki 10 kantor cabang yang tersebar di selururuh Kabupaten Purworejo dengan kantor pusat bertempat di jalan Urip Sumoharjo 80 Purworejo Kode Pos 54111, Kabupaten Purworejo, Provinsi Jawa Tengah. KJKS BMT Binamas merupakan salah satu lembaga keuangan mikro syariah yang bergerak di bidang jasa keuangan syariah. KJKS BMT Binamas merupakan sebuah lembaga keuangan mikro syariah yang beroperasi layaknya perbankan, tentu dituntut untuk berlaku amanah dan profesional sehingga masyarakat dapat terus percaya pada KJKS BMT Binamas Purworejo (Subyantomo, 2015).

Tabel 2 Kondisi Keuangan KJKS BMT Binamas

\begin{tabular}{lrrr}
\hline \multicolumn{1}{c}{ Komponen } & \multicolumn{1}{c}{$\mathbf{2 0 1 2}$} & \multicolumn{1}{c}{$\mathbf{2 0 1 3}$} & \multicolumn{1}{c}{$\mathbf{2 0 1 4}$} \\
\hline Jumlah Ekuitas & $3,629,979,522$ & $4,800,334,309$ & $7,026,842,722$ \\
\hline Total Aset & $62,639,636,682$ & $76,858,634,289$ & $91,388,577,155$ \\
\hline SHU & $342,447,639$ & $462,395,203$ & $615,584,996$ \\
\hline Pendapatan & $11,126,562,335$ & $13,364,128,901$ & $14,973,146,819$ \\
\hline Biaya Operasional & $10,477,726,340$ & $12,460,190,448$ & $13,841,920,856$ \\
\hline
\end{tabular}

Sumber diolah: Laporan Keuangan KJKS BMT Binamas 2012-2014

Secara umum memang KJKS BMT Binamas selalu mengalami kenaikan jika dilihat dari tabel di atas. Di sini yang perlu disoroti yaitu tingkat efisiensi yang dimiliki KJKS BMT Binamas. Dari tabel tersebut terlihat pada tahun 2012 KJKS memiliki pendapatan yaitu 
Rp11,126,562,335,- akan tetapi ditahun yang sama juga memiliki biaya operasional Rp10,477,726,340,-. Jika dirasiokan BMT Binamas hanya mendapatkan keuntungan $6 \%$ dari biaya yang telah dikeluarkan, ini merupakan tingkat pendapatan yang dapat dikatakan rendah, dan pada tahun 2013 dan 2014 juga dapat dikatakan tidak ada perubahan yang berarti. Padahal dengan biaya operasional yang ada menurut Kementrian Koperasi seharusnya sebuah KJKS mampu mendapatkan pendapatan sebesar lebih dari 147\% (Kementerian Koperasi, 2007, hlm.25).

Dalam penelitian ini akan digunakan standar penilaian Peraturan Menteri Negara Koperasi Dan Usaha Kecil dan Menengah Republik Indonesia Nomor: 35.3/Per/M.KUKM/X/2007 tentang Pedoman Penilaian Koperasi Jasa Keuangan Syariah Dan Unit Jasa Keuangan Syariah Koperasi dalam menganalisa tingkat kesehatan KJKS BMT Binamasdengan menggunakan delapan variable yaitu (1) permodalan; (2) kualitas aktiva produktif; (3) manajemen; (4) efisiensi; (5) likuiditas; (6) kemandirian dan pertumbuhan; (7) jati diri Koperasi; serta (8) kepatuhan prinsip syariah; dalam menganalisis penilaian kesehatan KJKS BMT Binamas di Kab. Purworejo.

\section{LANDASAN TEORI}

\subsection{KOPERASI JASA KEUANGAN SYARIAH (KJKS)}

\subsubsection{Pengertian Baitul Maal Wat Tamwil (BMT)}

Menurut Peraturan Menteri Negara Koperasi dan Usaha Kecil dan Menengah Republik Indonesia Nomor: 35.3/Per/M.KUKM/X/2007 tentang Pedoman Pelaksanaan Penilaian Kesehatan Koperasi Jasa Keuangan Syariah dan Unit Jasa Keuangan Syariah Koperasi, pengertian KJKS adalah lembaga koperasi yang melakukan kegiatan usaha pembiayaan, investasi, dan simpanan berdasarkan pola syariah yang perlu dikelola secara profesional sesuai dengan prinsip kehati-hatian dan kesehatan, sehingga dapat meningkatkan kepercayaan dan memberikan manfaat sebesar-besarnya kepada anggota dan masyarakat di sekitarnya. (Kementerian Koperasi, 2007, hlm.1)

Sedangkan Baitul Maal wat Tamwil (BMT) adalah sebuah lembaga keuangan yang berbadan hukum Koperasi Jasa Keuangan Syariah. Di Indonesia lembaga ini belakangan populer seiring dengan semangat umat Islam untuk mencari model ekonomi alternatif pasca krisis ekonomi tahun 1997. Kemunculan BMT merupakan usaha untuk memberdayakan ekonomi masyarakat. BMT memiliki perbedaan dengan lembaga keuangan seperti halnya perbankan. BMT tidak tunduk kedalam aturan perbankan yang ketat, hal ini disebabkan karena BMT tidak berada di bawah naungan Bank Indonesia tetapi di bawah pembinaan Kementerian Negara Koperasi dan UKM, sehingga bersifat fleksibel disesuaikan dengan kondisi di dalam masyarakat. Selain itu karyawan ataupun staf diharuskan mampu berperan aktif, dinamis, kreatif, proaktif, dan tidak menunggu melainkan menjemput 
pelanggan atau nasabah maupun anggota (Felayaty \& Chadhiq, 2014, hlm.54).

\subsection{TINGKAT KESEHATAN BMT}

Penilaian tingkat kesehatan merupakan kegiatan penting bagi perusahaan, karena dengan penilaian tingkat kesehatan tersebut akan dapat diketahui sejauh mana perusahaan (berdasarkan kriteria dan ukuran tertentu) dapat dipandang berhasil atau kurang berhasil dalam menjalankan usahanya. Hasil penilaian tingkat kesehatan tersebut dapat dipergunakan sebagai bahan pertimbangan dan bahkan pedoman guna membenahi, memperbaiki, mengubah, atau menghentikan suatu kebijakan manajemen perusahaan (Sugiyarso, 2011, hlm.130).

Sama halnya juga koperasi yang juga salah satu pelaku dalam perekonomian, bahkan mempunyai peranan besar dalam perekonomian rakyat. Oleh karena itu, koperasi agar dapat bersaing dengan perusahaan lain harus dalam kondisi sehat. Untuk kepentingan tersebut, penilaian kesehatan koperasi harus dilakukan secara periodik (Sugiyarso, 2011, hlm.130). Tingkat kesehatan Koperasi Syariah adalah suatu kondisi sebuah yang dinyatakan dalam kategori Sehat, Cukup Sehat, Kurang Sehat, dan Tidak Sehat (Buchori, 2012, hlm.229).

Aspek kesehatan BMT secara garis besar dapat dilihat dari dua aspek, yaitu aspek kinerja keuangan, serta kelembagaan dan manajemen:

1. Kinerja Keuangan: BMT mampu melakukan penggalangan, pengaturan, penyaluran, dan penempatan dana dengan baik, teliti, hati-hati, dan benar, sehingga berlangsung kelancaran arus pendanaan dalam pengelolaan kegiatan usaha.

2. Kelembagaan dan Manajemen: BMT memiliki kesiapan untuk melakukan operasinya dilihat dari sisi kelengkapan legalitas, aturanaturan, dan mekanisme organisasi dalam perencanaan, pelaksanaan, pendampingan dan pengawasan, SDM, permodalan, sarana, dan prasarana kerja.

\subsection{PENILAIAN KESEHATAN KJKS (BMT) BERDASARKAN PERATURAN MENTERI} NEGARA KUKM RI NOMOR: 35.3/PER/M.KUKM/X/2007

\subsubsection{Ruang Lingkup Penilaian Kesehatan KJKS (BMT)}

Penilaian kesehatan perusahaan dapat didasarkan pada standar atau pedoman penilaian tertentu menurut kepentingan masing-masing perusahaan. Penilaian kesehatan yang tergolong jenis koperasi dapat didasarkan pada Peraturan Menteri Negara Koperasi Dan Usaha Kecil dan Menengah Republik Indonesia Nomor: 35.3/Per/M.KUKM/X/2007 tentang pedoman penilaian kesehatan KJKS dan UJKS Koperasi yang mencakup delapan variable. yaitu, permodalan, kualitas aktiva produktif, manajemen, efisiensi dan likuiditas, kemandirian dan pertumbuhan, serta jati diri koperasi serta kepatuhan prinsip syariah (Sugiyarso, 2011, hlm.133). 


\subsubsection{Penetapan Kesehatan BMT}

Berdasarkan hasil penilaian terhadap delapan aspek sebagaimana dimaksud di atas maka diperoleh skor secara keseluruhan. Penetapan predikat kesehatan serupa secara parsial berdasarkan aspek yang dinilai juga dapat dilihat pada masing-masing penilaian aspek yang sudah dijelaskan di atas. Penetapan predikat tingkat kesehatan KJKS dan UJKS Koperasi tersebut adalah sebagai berikut:

Tabel 3 Penetapan Prediksi Tingkat Kesehatan KJKS

\begin{tabular}{cc}
\hline Kriteria Tingkat Kesehatan & Skor \\
\hline SEHAT & $81-100$ \\
\hline CUKUP SEHAT & $66<80$ \\
\hline KURANG SEHAT & $51<66$ \\
\hline TIDAK SEHAT & $0<51$
\end{tabular}

Sumber diolah: Peraturan Menteri Negara KUKM RI No 35.3/Per/M.KUKM/X/2007.

\section{METODOLOGI PENELITIAN}

\subsection{JENIS DAN SUMBER DATA}

Jenis data yang digunakan dalam penelitian ini adalah data primer dan data sekunder. Data primer yang digunakan adalah data hasil wawancara dan observasi mengenai aspek manajemen dan kepatuhan terhadap prinsip syariah KJKS BMT Binamas. Adapun data sekunder yang digunakan adalah data profil KJKS BMT Binamas, laporan keuangan KJKS BMT Binamas tahun 2012-2014, dan data pembiayaan dan piutang bermasalah KJKS BMT Binamas tahun 2012-2014.

\subsection{TEKNIK PENGUMPULAN DATA}

\subsubsection{Riset Kepustakaan (Library Research)}

Berbagai teori dan alat analisis diperoleh dari UUD, Peraturan Menteri, situs online, buku, jurnal, karya ilmiah, dan laporan keuangan yang relevan yang berkaitan dengan pembahasan skripsi ini. Teori-teori tersebut disusun menjadi analisis masalah kemudian akan dibandingkan kesamaan data yang diperoleh dengan praktek setelah dilakukan penelitian.

\subsubsection{Riset Lapangan (Field Risearch)}

Ada dua cara yang dilakukan penulis dalam mengumpulkan data, yakni:

1. Observasi: Penelitian yang dilakukan dengan cara melakukan pencatatan data yang diperoleh berupa data yang dibutuhkan penulis untuk objek penelitian dari laporan keuangan KJKS BMT Binamas dari tahun 2012 sampai dengan 2014.

2. Wawancara (Interview): Penelitian yang dilakukan dengan mengadakan tanya jawab langsung kepada Manajer Koperasi. 


\subsection{OPERASIONALISASI VARIABEL}

Variable yang digunakan dalam penelitian ini mengacu pada Peraturan Menteri Negara KUKM RI Nomor: 35.3/Per/M.KUKM/X/2007 tentang pedoman penilaian kesehatan KJKS dan UJKS Koperasi.

Tabel 4 Pendekatan Variabel Penelitian

\begin{tabular}{|c|c|c|}
\hline No & Variabel & Pendekatan Penelitian \\
\hline 1 & Permodalan & Kuantitatif \\
\hline 2 & Kualitas aktiva produktif & Kuantitatif \\
\hline 3 & Manajemen & Kualitatif \\
\hline 4 & Efisiensi & Kuantitatif \\
\hline 5 & Likuiditas & Kuantitatif \\
\hline 6 & Kemandirian dan pertumbuhan & Kuantitatif \\
\hline 7 & Jati diri Koperasi & Kuantitatif \\
\hline 8 & Kepatuhan prinsif syariah & Kualitatif \\
\hline
\end{tabular}

\subsection{METODE ANALISIS DATA}

Jenis penelitian yang digunakan dalam penelitian ini adalah penelitian deskriptif kuantitatif. Metode analisis data dalam penelitian ini menggunakan standar Penilaian Peraturan Menteri Negara Koperasi Dan Usaha Kecil dan Menengah Republik Indonesia Nomor: 35.3/Per/M.KUKM/X/2007 tentang pedoman penilaian kesehatan KJKS dan UJKS Koperasi.

Tabel 5 Bobot Penilaian Variabel dan Komponen Kesehatan KJKS

\begin{tabular}{cccc}
\hline No & $\begin{array}{c}\text { Variabel Yang } \\
\text { Dinilai }\end{array}$ & Komponen & $\begin{array}{c}\text { Bobot } \\
\text { Penilaian (\%) }\end{array}$ \\
\hline \multirow{4}{*}{1} & & a. Rasio Modal Sendiri Terhadap Total Modal: \\
& & $\frac{\text { Modal Sendiri X 100\% }}{\text { Total Modal }}$ & 5 \\
& Permodalan & b. Rasio Kecukupan Modal (CAR): & 10 \\
\cline { 3 - 4 } & & $\frac{\text { Modal Tertimbang X 100\% }}{\text { ATMR }}$ & 5 \\
\hline
\end{tabular}

a. Rasio Tingkat Pembiayaan Dan Piutang

Bermasalah Terhadap Jumlah Piutang dan

Pembiayaan:

$\underline{\text { Jumlah Pembiayaan \& Piutang Bermasalah X 100\% }}$

Jumlah Piutang Dan Pembiayaan

$2 \begin{gathered}\text { Kualitas Aktiva } \\ \text { Produktif }\end{gathered}$

b. Rasio Portofolio Pembiayaan Berisiko: Jumlah Portofolio Berisiko X 100\% Jumlah Piutang Pembiayaan

c. Rasio Penyisihan Penghapusan Aktiva Produktif (PPAP):

PPAP X $100 \%$

PPAWD

a. Manajemen Umum: Interview guide

3

b. Kelembagaan: Interview guide

3 Manajemen

c. Manajemen Permodalan: Interview guide

d. Manajemen Aktiva: Interview guide

e. Manajemen Likuiditas: Interview guide 


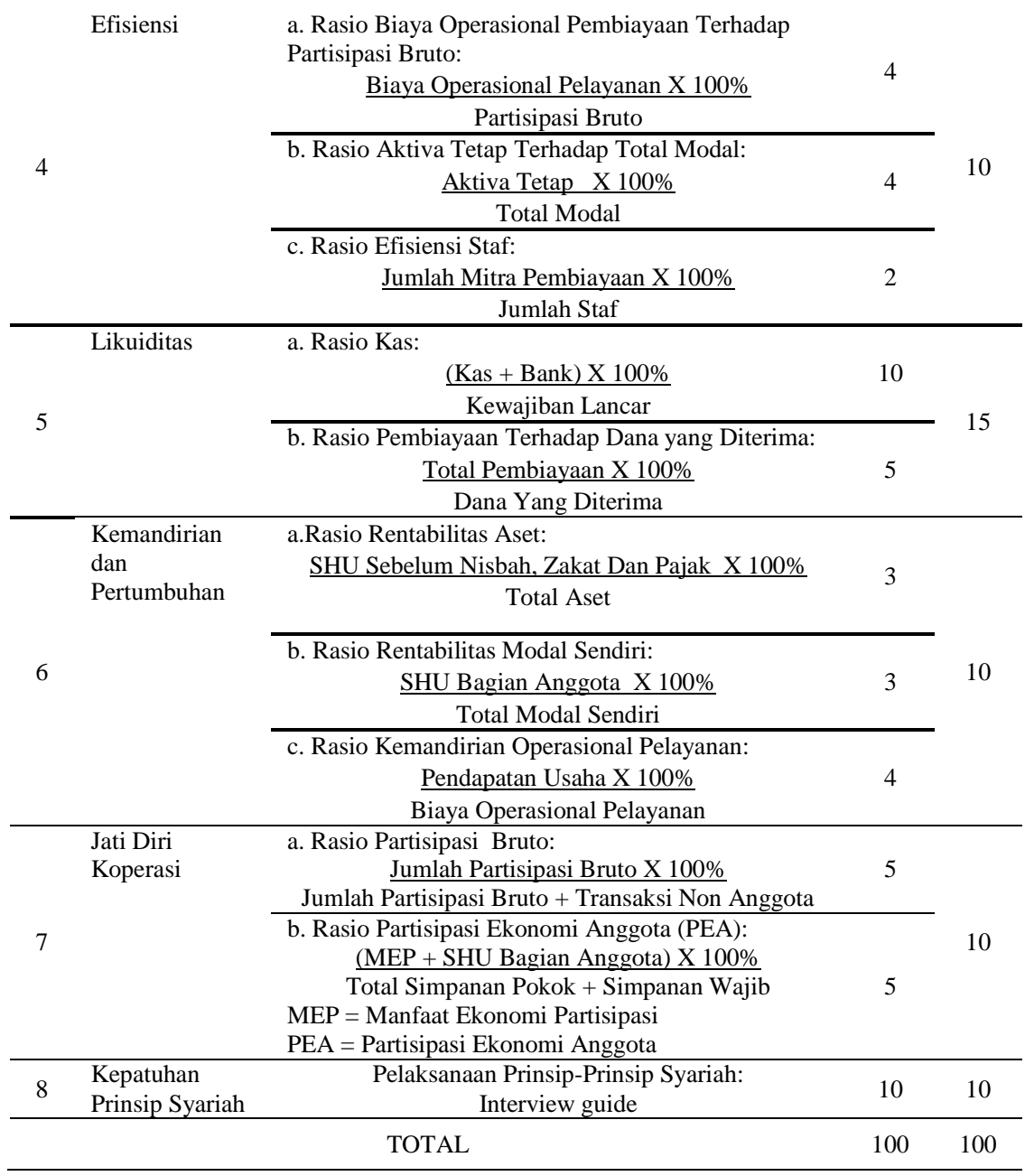

Sumber diolah: Peraturan Menteri Negara KUKM RI No 35.3/Per/M.KUKM/X/2007.

\section{PEMBAHASAN}

Berdasarkan Peraturan Menteri Negara Koperasi dan UKM Republik Indonesia Nomor: 35.3/Per/M.KUKM/X/2007 tentang Penilaian Kesehatan KJKS, bahwa penilaian kesehatan ini bertujuan untuk memberikan pedoman bagi pihak yang akan menilai kesehatan sebuah Koperasi Jasa Keuangan Syariah, diharapkan penilaian kesehatan ini dapat membantu dalam meningkatkan kredibilitas dan memberikan manfaat kepada anggota dan masyarakat di sekitarnya. Adapun perhitungan penilaian kesehatan KJKS BMT Binamas berdasarkan laporan keuangan tahun 2012-2014 dan hasil observasi adalah sebagai berikut: 


\subsubsection{Perhitungan Aspek Permodalan}

\section{Rasio Modal Sendiri Terhadap Total Modal}

Rasio pertama yang digunakan dalam menilai aspek permodalan yaitu rasio modal sendiri terhadap total modal. Modal sendiri (ekuitas) KJKS adalah jumlah simpanan pokok, simpanan wajib, dan simpanan lain yang memiliki ciri-ciri simpanan serta hibah, dan cadangan yang disisihkan dari Sisa Hasil Usaha tahun berjalan yang tidak dibagi.

Rasio ini dimaksudkan untuk mengukur kecukupan modal sendiri (simpanan pokok, simpanan wajib, donasi, dan cadangan) dibandingkan dengan total modal. Rasio modal sendiri terhadap total modal pada KJKS dianggap sehat apabila memiliki nilai lebih dari $15 \%$, artinya bahwa KJKS telah dipercaya oleh anggotanya untuk menyimpan dananya pada KJKS. Berdasarkan data, dapat diketahui bahwa rasio modal sendiri terhadap total modal pada tahun 2012 sebesar 31.36\%, dan pada tahun 2013 mengalami kenaikan menjadi 31.84\%, selanjutnya pada tahun 2014 juga mengalami kenaikan menjadi $42.65 \%$. Kenaikan itu terjadi karena walaupun total modal di setiap tahunnya mengalami kenaikan yang cukup drastis, tetapi total modal sendiri juga terus konsisten naik dengan persentase yang lebih tinggi.

Rasio modal sendiri terhadap total modal pada tahun 2012 sampai tahun 2014 mendapat skor 5.00 dengan bobot skor persentase 0 sampai 5 sehingga dapat dikatagorikan Sehat. Artinya KJKS sangat optimal dalam menghimpun modal sendiri, sehingga memiliki modal sendiri yang cukup dibandingkan dengan total modal yang dimiliki. Keadaan ini perlu dipertahankan agar KJKS dapat terus dipercaya oleh anggotanya untuk menyimpan dananya pada KJKS.

2. Rasio Kecukupan Modal (CAR)

Perhitungan Rasio CAR diperoleh dengan cara, membandingkan nilai modal yang diakui terhadap nilai ATMR dikalikan dengan 100\%. Pada perhitungan di atas dapat dikatakan selama tiga tahun tersebut KJKS masih dibawah standar rasio kecukupan modal yaitu memiliki standar minimal $7.99 \%$ dengan kriteria sehat, hal tersebut dikarenakan jumlah modal inti dan modal pelengkap yang ada masih belum mencukupi atau mengimbangi nilai aktifa tertimbang menurut risiko. Dari data yang ada, dihitung rasio modal sendiri terhadap total modal pada tahun 2012 sebesar 6.06\%, dan pada tahun 2013 mengalami kenaikan menjadi 6.80\%, selanjutnya pada tahun 2014 juga mengalami kenaikan menjadi $8.02 \%$. Kenaikan nilai rasio di setiap tahunnya terjadi karena walaupun total ATMR di setiap tahunnya mengalami kenaikan, tetapi total modal inti dan pelengkap juga terus konsisten naik dengan persentase yang lebih tinggi.

Rasio modal sendiri terhadap total modal pada tahun 2012 mendapat skor 2.50 dengan bobot skor persentase 0 sampai 5 sehingga dapat dikatagorikan Kurang Sehat, dan pada tahun 2013 mengalami kenaikan menjadi 2.50 dengan katagori Kurang Sehat, kemudian pada tahun 2014 juga mengalami kenaikan menjadi 5.00 dengan katagori Sehat. 
Dari skor tersebut dapat diartikan bahwa KJKS selama tahun 2012 sampai tahun 2013 dengan pengembangan usaha yang ada kurang dapat menanggung risiko kerugian dalam batas-batas tertentu yang dapat diantisipasi oleh modal yang ada. Tetapi perbaikan terus dilakukan oleh KJKS sehingga di setiap tahunnya selalu mengalami peningkatan positif dari nilai rasio, dan pada tahun 2014 KJKS memiliki kriteria Sehat atas modalnya sehingga dapat mengembangkan usaha dengan lebih baik.

\subsubsection{Perhitungan Aspek Kualitas Aktiva Produktif}

1. Rasio Pembiayaan dan Piutang Bermasalah

Rasio pembiayaaan dan piutang bermasalah terhadap piutang dan pembiayaan yang disalurkan digunakan untuk mengukur risiko gagalnya pengembalian pembiayaan yang mengalami kemacetan dibandingkan dengan keseluruhan pembiayaan yang diberikan pada periode yang sama. Pada perhitungan ini KJKS dikatakan lancar apabila rasio piutang dan pembiayaan bermasalah kurang dari 5\%. Berdasarkan data, dapat diketahui bahwa rasio pembiayaaan dan piutang bermasalah pada tahun 2012 sebesar $0.56 \%$, dan pada tahun 2013 mengalami kenaikan menjadi $0.55 \%$, selanjutnya pada tahun 2014 mengalami penurunan menjadi $0.52 \%$. Nilai rasio yang konsisten dinilai tinggi tersebut terjadi karena walaupun jumlah pembiayaan selalu meningkat di setiap tahunnya tetapi KJKS terus menjaga jumlah pembiayaan bermasalah dibawah $5 \%$.

Rasio pembiayaaan dan piutang bermasalah pada tahun 2012 sampai tahun 2014 tidak mengalami perubahan, yaitu konsisten dengan skor 10.00 dengan bobot skor persentase 0 sampai 10 sehingga dapat dikatagorikan Lancar, artinya dapat dikatakan KJKS memiliki risiko pembiayaan bermasalah yang sangat kecil, atau kegagalan pengembalian pembiayaan sedikit ditemukan.

2. Rasio Portofolio Pembiayaan Berisiko

Rasio portofolio piutang dan pembiayaan berisiko digunakan untuk mengukur kemungkinan risiko macetnya pengembalian pembiayaan dari piutang dan pembiayaan yang telah disalurkan di periode yang sama. Pada perhitungan ini KJKS dikatakan tidak berisiko apabila rasio portofolio pembiayaan berisiko kurang dari $21 \%$. Berdasarkan data, dapat diketahui bahwa rasio portofolio piutang dan pembiayaan berisiko pada tahun 2012 sebesar $0.75 \%$, dan pada tahun 2013 mengalami penurunan menjadi $0.75 \%$, selanjutnya pada tahun 2014 juga mengalami penurunan menjadi $0.74 \%$. Nilai rasio yang konsisten dinilai tinggi tersebut terjadi karena walaupun jumlah pembiayaan yang disalurkan selalu meningkat di setiap tahunnya tetapi KJKS terus menjaga jumlah portofolio berisiko tetap dibawah $21 \%$.

Rasio portofolio piutang dan pembiayaan berisiko pada tahun 2012 sampai 2014 tidak mengalami perubahan, yaitu konsisten dengan skor 5.00 dengan bobot skor persentase 0 sampai 5 sehingga dapat dikatagorikan Tidak Berisiko, artinya KJKS memiliki risiko macetnya pengembalian pembiayaan 
dan piutang sangat kecil atau sedikit ditemukan mitra yang telat dan gagal bayar.

\section{Rasio Penyisihan Penghapusan Aktiva Produktif (PPAP)}

Pada perhitungan ini KJKS dapat dikatakan lancar apabila rasio portofolio pembiayaan berisiko minimal $75 \%$. Berdasarkan data, dapat diketahui bahwa rasio penyisihan penghapusan aktiva produktif pada tahun 2012 sebesar $30.36 \%$, dan pada tahun 2013 sedikit mengalami penurunan menjadi $30.30 \%$, selanjutnya pada tahun 2014 mengalami kenaikan menjadi 30.96\%. Nilai rasio yang konsisten diangka rendah tersebut terjadi karena walaupun PPAP yang ada selalu meningkat di setiap tahunnya tetapi PPAPWD juga terus mengalami peningkatan.

Rasio penyisihan penghapusan aktiva produktif pada tahun 2012 mendapat skor 1.52 dengan bobot skor persentase 0 sampai 5 sehingga dapat dikatagorikan Diragukan, dan pada tahun 2013 masih dengan angka yang sama yaitu 1.52 dengan katagori Diragukan, kemudian pada tahun 2014 mengalami kenaikan menjadi 1.55 dengan masih dalam katagori Diragukan. Artinya kemampuan manajeman KJKS belum optimal dalam menyisihkan pendapatannya untuk menutupi risiko (penghapusan) aktiva produktif yang disalurkan dalam bentuk pembiayaan dan piutang. Tetapi perbaikan terus dilakukan oleh KJKS yang dapat dilihat dari nilai rasio di tahun 2014 yang lebih baik dari dua tahun sebelumnya.

\subsubsection{Perhitungan Aspek Manajemen}

Berdasarkan data, dapat diketahui bahwa perhitungan aspek manajemen umum tahun 2012 sampai tahun 2014 mendapatkan nilai positif 12 dari 12 pertanyaan sehingga dapat dikatagorikan Baik. Perhitungan aspek kelembagaan tahun 2012 sampai dengan tahun 2014 mendapatkan nilai positif 5 dari 6 pertanyaan sehingga dapat dikatagorikan Cukup Baik, dan untuk aspek manajemen permodalan tahun 2012 sampai dengan tahun 2014 mendapatkan nilai positif 3 dari 5 pertanyaan sehingga dapat dikatagorikan Cukup Baik.

Kemudian untuk perhitungan aspek manajemen aktiva tahun 2012 sampai dengan tahun 2014 mendapatkan nilai positif 7 dari 10 pertanyaan sehingga dapat dikatagorikan Cukup Baik, dan untuk aspek manajemen likuiditas tahun 2012 sampai dengan tahun 2014 mendapatkan nilai positif 5 dari 5 pertanyaan sehingga dapat dikatagorikan Baik. Artinya dari tabel tersebut selama tahun 2012 sampai dengan tahun 2014 KJKS tidak mengalami perubahan dalam aspek manajemen yang dijalankan, ini dapat dilihat dari tidak adanya perubahan nilai positif selama jarak waktu tersebut. Dari penilaian yang ada KJKS telah menerapkan manajemen secara keseluruhan dengan cukup baik, walaupun masih ada beberapa kekurangan yang harus segera diperbaiki, seperti masih adanya rangkap jabatan, kurang efektifnya prosedur pembiayaan, dana cadangan yang masih sangat kecil, dan pertumbuhan modal sendiri yang masih cukup lambat.

\subsubsection{Perhitungan Aspek Efisiensi}




\section{Rasio Biaya Operasional Pelayanan terhadap Partisipasi Bruto}

Perhitungan ini digunakan untuk mengukur tingkat efisiensi KJKS dengan membandingkan besarnya biaya operasional atas partisipasi bruto. Nilai 1 apabila biaya operasionalnya lebih tinggi dari pendapatan, dan KJKS dikatakan efisien apabila rasio biaya operasional maksimal 68\%. Berdasarkan data, dapat diketahui bahwa rasio biaya operasional pelayanan terhadap partisipasi bruto pada tahun 2012 sebesar 94.90\%, dan pada tahun 2013 mengalami penurunan menjadi 93.77\%, selanjutnya pada tahun 2014 juga mengalami penurunan menjadi $92.81 \%$. Nilai rasio yang konsisten diangka rendah tersebut terjadi karena walaupun partisipasi bruto selalu meningkat di setiap tahunnya tetapi biaya operasionalnya masih cukup tinggi.

Rasio biaya operasional pelayanan terhadap partisipasi bruto pada tahun 2012 sampai dengan tahun 2014 mendapat skor 2.00 dengan bobot skor persentase 0 sampai 4 sehingga dapat dikatagorikan Kurang Efisien, artinya KJKS kurang efisien dalam mengeluarkan biaya operasional atau pendapatannya relatif masih kurang atau kecil dibanding biaya operasional yang dikeluarkan. Tetapi perbaikan terus dilakukan oleh KJKS yang dapat dilihat dari angka rasio yang selalu turun di setiap tahunnya.

2. Rasio Aktiva Tetap terhadap Total Modal

Perhitungan ini digunakan untuk menilai tingkat efisiensi pembelian aktiva tetap dibandingkan nilai total modal yang dimiliki BMT. Nilai 1 apabila nilai aktiva tetapnya lebih dari $75 \%$ dari total modal, dan KJKS dikatakan baik apabila memiliki rasio aktiva tetap kurang dari $26 \%$. Berdasarkan data, dapat diketahui bahwa rasio biaya aktiva tetap terhadap total aset pada tahun 2012 sebesar 64.50\%, dan pada tahun 2013 mengalami kenaikan menjadi 69.79\%, selanjutnya pada tahun 2014 mengalami penurunan menjadi $50.39 \%$. Secara umum tingkat efisiensi aktiva tetap masih kurang baik, dan penurunan nilai rasio di tahun 2014 terjadi karena walaupun aktiva tetap di setiap tahunnya mengalami kenaikan tetapi peningkatan total modal di tahun tersebut melonjak cukup drastis.

Rasio aktiva tetap terhadap total aset pada tahun 2012 sampai dengan tahun 2013 mendapat skor 2.00 dengan bobot skor persentase 0 sampai 4 sehingga dapat dikatagorikan Kurang Baik, kemudian pada tahun 2014 mengalami kenaikan skor yaitu 3.0 dengan kategori Cukup Baik. Artinya KJKS masih kurang efisien dalam membelanjakan aktiva tetapnya yang bahkan masih melebihi separuh nilai modalnya.

3. Rasio Efisiensi Staf

Perhitungan ini dipergunakan untuk mengukur tingkat efisiensi atau optimalisasi keseluruhan staf KJKS dalam memberikan pelayanan terhadap mitra pembiayaan. Nilai 1 apabila skalanya seorang staf melayani kurang dari 50 orang mitra pembiayaan, dan nilai 2 apabila seorang staf melayani lebih dari 99 orang. Berdasarkan data, dapat diketahui bahwa perhitunganefisiensi staf pada tahun 2012 sebesar satu staf berbanding 370.78 mitra pembiayaan, dan pada tahun 2013 mengalami kenaikan menjadi satu staf berbanding 424.58 mitra pembiayaan, selanjutnya pada tahun 2014 juga mengalami 
kenaikan menjadi satu staf berbanding 458.58 mitra pembiayaan. Kenaikan rasio tersebut terjadi karena walaupun jumlah staf di setiap tahunnya bertambah, tetapi jumlah mitra pembiayaan juga terus konsisten naik dengan persentase yang lebih tinggi.

Rasio efisiensi staf pada tahun 2012 sampai dengan tahun 2014 mendapat skor 2.00 dengan bobot skor persentase 0 sampai 2 sehingga dapat dikatagorikan Baik, artinya KJKS cukup efisien dalam mengoptimalisasikan seluruh staf dalam memberikan pelayanan terhadap mitra pembiayaan.

\subsubsection{Perhitungan Aspek Likuiditas}

\section{Rasio Kas}

Rasio ini digunakan untuk menunjukkan kemampuan KJKS dalam mengelola dana kasnya dan di satu sisi harus dapat memenuhi hutang jangka pendeknya (simpanan, tabungan dan simpanan berjangka yang telah jatuh tempo), serta di sisi lain KJKS juga harus mengusahakan agar jangan terlalu besar kasnya, agar lebih produktif karena dananya tersalurkan. Kondisi ideal terjadi apabila besaran kasnya 26\% - 34\% dari hutang lancarnya. Berdasarkan data, dapat diketahui bahwa rasio kas pada tahun 2012 sebesar 23.37\%, dan pada tahun 2013 mengalami kenaikan menjadi 25.99\%, selanjutnya pada tahun 2014 mengalami penurunan menjadi $18.66 \%$. Secara umum tingkat likuiditas kas masih kurang baik, dan penurunan nilai rasio di tahun 2014 terjadi karena kenaikan kewajiban lancar cukup drastis yang dibarengi dengan penurunan nilai kas.

Rasio kas pada tahun 2012 mendapat skor 7.50 dengan bobot skor persentase 0 sampai 10 sehingga dapat dikatagorikan Cukup Likuid, dan pada tahun 2013 masih dengan skor yang sama 7.50 dengan katagori Cukup Likuid, kemudian pada tahun 2014 mengalami penurunan menjadi 5.00 dengan katagori Kurang Likuid, artinya KJKS belum optimal dan mencukupi dalam menyediakan kas untuk mengantisipasi pengambilan simpanan oleh anggota, dalam arti lain KJKS secara teoritis belum memiliki kemampuan yang cukup dalam memenuhi hutang jangka pendeknya.

Rasio Pembiayaan terhadap Dana yang Diterima

Penilaian ini dalam perbankan dikenal dengan Loan to Deposit Ratio (LDR) atau Financing to Deposit Ratio (FDR) untuk perbankan syariah, yakni menilai kemampuan BMT dalam mengoptimalkan dana hutang yang diterima untuk pembiayaan produktifnya. Nilai 1 apabila BMT hanya menggunakan kurang dari 50\%, dan nilai 4 apabila menggunakan lebih dari total hutangnya (artinya menggunakan juga modal) untuk pembiayaan produktifnya. Berdasarkan data, dapat diketahui bahwa rasio pembiayaan terhadap dana yang diterima pada tahun 2012 sebesar $106.43 \%$, dan pada tahun 2013 mengalami penurunan menjadi 102.29\%, selanjutnya pada tahun 2014 mengalami kenaikan menjadi $100.72 \%$. Penurunan rasio tersebut terjadi karena walaupun dana yang diterima di setiap tahunnya selalu mengalami peningkatan, tetapi jumlah pembiayaan juga terus konsisten naik dengan persentase yang lebih tinggi. 
Rasio pembiayaan terhadap dana yang diterima pada tahun 2012 sampai dengan tahun 2014 mendapat skor 5.00 dengan bobot skor persentase 0 sampai 5 sehingga dapat dikatagorikan Likuid, artinya KJKS sangat optimal dalam memanfaatkan dana hutangnya untuk pembiayaan produktif.

\subsubsection{Perhitungan Aspek Kemandirian dan Pertumbuhan}

\section{Rasio Rentabilitas Aset}

Rasio di atas untuk mengukur kemampuan manajemen KJKS dalam mengelola harta yang dikuasainya untuk menghasilkan laba kotor. Nilai 0.75 apabila KJKS hanya menghasilkan laba kotor kurang dari 5\% dari total aset, dan nilai 3 apabila laba kotor lebih dari 10\%. Berdasarkan data, dapat diketahui bahwa rasio rentabilitas aset pada tahun 2012 sebesar $0.55 \%$, dan pada tahun 2013 mengalami kenaikan menjadi $0.60 \%$, selanjutnya pada tahun 2014 juga mengalami kenaikan menjadi $0.67 \%$. Nilai rasio yang konsisten diangka yang rendah tersebut terjadi karena walaupun SHU Sebelum Nisbah, Zakat dan Pajak yang ada selalu meningkat di setiap tahunnya dan total aset juga terus mengalami peningkatan.

Rasio rentabilitas aset pada tahun 2012 sampai dengan tahun 2014 tidak mengalami kenaikan ataupun penurunan yaitu mendapat skor 0.75 dengan bobot skor persentase 0 sampai 3 sehingga dapat dikatagorikan Rendah, artinya KJKS masih sangat kecil menghasilkan laba atau dalam artian pengelolan harta keseluruhan belum dapat maksimal dalam menghasilkan laba kotor. Tetapi perbaikan terus dilakukan oleh KJKS yang dapat dilihat dari nilai rasio yang selalu meningkat di setiap tahunnya.

\section{Rasio Rentabilitas Ekuitas}

Rasio di atas untuk mengukur kemampuan manajemen KJKS dalam menghasilkan laba bersih ditinjau dari sudut kekuatan modal sendiri KJKS. Nilai 0.75 apabila KJKS hanya menghasilkan laba bersih kurang dari 5\% dari modal sendiri dan nilai 3 apabila laba bersih lebih dari 10\%. Berdasarkan data, dapat diketahui bahwa rasio rentabilitas ekuitas pada tahun 2012 sebesar 24.78\%, dan pada tahun 2013 mengalami penurunan menjadi $23.58 \%$, selanjutnya pada tahun 2014 juga mengalami penurunan menjadi $14.48 \%$. Walaupun nilai rasio mengalami penurunan tetapi nilai rasio masih konsisten diangka yang tinggi, hal tersebut terjadi karena KJKS terus mempertahankan SHU bagian anggota di atas 5\% dari total modal sendiri.

Rasio rentabilitas ekuitas pada tahun 2012 sampai dengan tahun 2014 tidak mengalami kenaikan ataupun penurunan yaitu mendapat skor 3.00 dengan bobot skor persentase 0 sampai 3 sehingga dapat dikatagorikan Tinggi, artinya pengelolan modal sendiri KJKS sangat optimal dalam menghasilkan laba bersih.

3. Rasio Kemandirian Operasional Pelayanan

Rasio di atas untuk mengukur tingkat keberlanjutan operasional lembaga. Nilai 1 apabila KJKS hanya menghasilkan pendapatan usaha kurang dari $100 \%$ dari biaya operasional pelayanan dan nilai 4 apabila nilai rasio pendapatan usaha lebih dari $150 \%$. Berdasarkan data, dapat diketahui bahwa 
rasio kemandirian operasional pada tahun 2012 sebesar $105.37 \%$, dan pada tahun 2013 mengalami kenaikan menjadi 106.65\%, selanjutnya pada tahun 2014 juga mengalami kenaikan menjadi $107.75 \%$. Secara umum tingkat kemandirian operasional pelayanan masih kurang baik, tetapi peningkatan nilai rasio di setiap tahunnya terjadi karena walaupun biaya operasional pelayanan di setiap tahunnya mengalami kenaikan tetapi peningkatan pendapatan usaha di setiap tahunnya juga meningkat dengan persentase yang sedikit lebih besar.

Rasio kemandirian operasional pada tahun 2012 sampai dengan tahun 2014 tidak mengalami kenaikan mau pun penurunan yaitu mendapat skor 2.00 dengan bobot skor persentase 0 sampai 4 sehingga dapat dikatagorikan Kurang, artinya KJKS kurang dalam membiayai kegiatan operasional lembaga, dengan kata lain KJKS dalam menjalankan operasional pelayanannya kurang efisien. Tetapi perbaikan terus dilakukan oleh KJKS yang dapat dilihat dari nilai rasio yang selalu meningkat di setiap taunnya.

\subsubsection{Perhitungan Aspek Jati diri Koperasi}

\section{Rasio Pertisipasi Bruto}

Rasio ini digunakan untuk mengukur tingkat kemampuan KJKS dalam melayani anggota, semakin tinggi presentasenya maka semakin baik. Rasio partisipasi bruto dianggap tinggi apabila memiliki nilai lebih dari $75 \%$. Berdasarkan data, dapat diketahui bahwa rasio partisipasi bruto pada tahun 2012 sampai tahun 2014 tidak mengalami kenailan ataupun penurunan yaitu sebesar $100.00 \%$. Nilai rasio yang konsisten diangka yang tinggi tersebut terjadi karena tidak adanya transaksi non-anggota (0), sehingga setiap mitra KJKS harus terdaftar terlebih dahulu menjadi anggota.

Rasio kemandirian operasional pada tahun 2012 sampai dengan tahun 2014 tidak mengalami kenaikan mau pun penurunan yaitu mendapat skor 5.00 dengan bobot skor persentase 0 sampai 5 sehingga dapat dikatagorikan Tinggi, artinya kemampuan KJKS dalam melayani anggota sangat baik. Walaupun nilai rasio terus stabil dinilai yang sama tetapi nominal partisipasi terus meningkat di setiap tahunnya.

\section{Rasio Partisipasi Ekonomi Anggota (PEA)}

Rasio ini digunakan untuk mengukur kemampuan KJKS dalam memberikan manfaat efisiensi partisipasi dan manfaat efisiensi biaya koperasi dengan simpanan pokok dan simpanan wajib, semakin tinggi presentasenya semakin baik. Rasio partisipasi ekonomi anggota dianggap bermanfaat apabila memiliki nilai minimal 13\%. Berdasarkan data, dapat diketahui bahwa rasio kemandirian operasional pada tahun 2012 sebesar 59.46\%, dan pada tahun 2013 mengalami penurunan menjadi $63.19 \%$, selanjutnya pada tahun 2014 juga mengalami penurunan menjadi $66.17 \%$. Nilai rasio yang konsisten tersebut terjadi karena KJKS terus menjaga MEP dan SHU bagian anggota di atas $12 \%$ dari total modal sendiri.

Rasio kemandirian operasional pada tahun 2012 sampai dengan tahun 2014 tidak mengalami kenaikan mau pun penurunan yaitu mendapat skor 
5.00 dengan bobot skor persentase 0 sampai 5 sehingga dapat dikatagorikan Bermanfaat, artinya pelayanan KJKS kepada anggotanya dalam bentuk manfaat ekonomi yang diperoleh sebagai anggota koperasi sangat baik. Manfaat tersebut mencakup manfaat yang diperoleh selama tahun berjalan dari transaksi pelayanan yang dilakukan koperasi untuk anggota (MEP) dan manfaat yang diperoleh pada akhir tahun buku dari pembagian sisa hasil usaha tahun berjalan

\subsubsection{Perhitungan Aspek Kepatuhan Prinsip Syariah}

Penilaian aspek kepatuhan prinsip syariah dimaksudkan untuk menilai sejauh mana prinsip syariah diterapkan atau dipatuhi oleh KJKS dalam melaksanakan aktivitasnya sebagai lembaga keuangan mikro syariah. Perhitungan kepatuhan prinsip syariah dianggap patuh apabila memiliki nilai positif minimal delapan.

Aspek kepatuhan prinsip syariah dianggap patuh apabila memiliki nilai positif minimal 8 (jawaban benar). Berdasarkan data, dapat diketahui bahwa perhitungan aspek kepatuhan prinsip syariah tahun 2012 sampai dengan tahun 2014 tidak mengalami kenaikan maupun penurunan yaitu mendapatkan nilai positif 6 dari 10 pertanyaan yang diajukan sehingga dapat dikatagorikan Cukup Patuh. Artinya KJKS dalam melaksanakan aktifitasnya sebagai lembaga keuangan mikro syariah selama menjalankan operasionalnya belum sepenuhnya patuh sesuai dengan aturan prinsip syariah yang ada, hal ini terjadi karena KJKS belum memiliki Dewan Pengawas Syariah (DPS) dan selama tahun tersebut tugas pengawasan syariah diperankan oleh pengurus KJKS, sehingga dapat dikatakan KJKS belum sesuai dengan peraturan yang seharusnya diterapkan.

\subsection{REKAPITULASI HASIL PERHITUNGAN VARIABEL PENILAIAN KESEHATAN KJKS BMT BINAMAS}

Dari hasil perhitungan variable di atas telah didapatkan nilai rasio, nilai skor, dan kriteria dari masing-masing komponen penilaian kesehatan. Kemudian hasil perhitungan tersebut direkapitulasi sesuai dengan tabel bobot penilaian variabel dan komponen kesehatan Penilaian Peraturan Menteri Negara Koperasi dan Usaha Kecil dan Menengah Republik Indonesia Nomor: 35.3/Per/M.KUKM/X/2007 tentang pedoman penilaian kesehatan KJKS dan UJKS Koperasi. Berikut adalah tabel rekapitulasi hasil perhitungan variabel penilaian kesehatan, dan tabel perbandingan rasio dan skor penilain kesehatan KJKS BMT Binamas tahun 2012-2014:

Tabel 6. Tabel Perbandingan Skor Penilaian Kesehatan KJKS BMT Binamas Tahun 2012-2014

\begin{tabular}{llcccc}
\hline $\mathrm{N}$ & \multirow{2}{*}{$\begin{array}{l}\text { Variabel Penilaian } \\
\mathrm{O}\end{array}$} & Kriteria Sehat & & \multicolumn{3}{c}{ Skor } \\
\cline { 4 - 6 } 1 & Permodalan: & & 2012 & 2013 & 2014 \\
\hline & $\begin{array}{l}\text { a. Rasio Modal Sendiri } \\
\text { terhadap Total Modal }\end{array}$ & $3.76-5.00$ & 5.00 & 5.00 & 5.00 \\
\hline
\end{tabular}




\begin{tabular}{|c|c|c|c|c|c|}
\hline & $\begin{array}{l}\text { b. Rasio Kecukupan Modal } \\
\text { (CAR) }\end{array}$ & 5.00 & 2.50 & 2.50 & 5.00 \\
\hline \multirow[t]{4}{*}{2} & Kualitas Aktiva Produktif: & & & & \\
\hline & $\begin{array}{l}\text { a. Rasio Tingkat Pembiayaan } \\
\text { Dan Piutang Bermasalah }\end{array}$ & $7.50-10.00$ & 10.00 & 10.00 & 10.00 \\
\hline & $\begin{array}{l}\text { b. Rasio Portofolio Pembiayaan } \\
\text { Berisiko }\end{array}$ & $3.75-5.00$ & 5.00 & 5.00 & 5.00 \\
\hline & $\begin{array}{l}\text { c. Rasio Penyisihan } \\
\text { Penghapusan Aktiva Produktif } \\
\text { (PPAP) }\end{array}$ & $3.75-5.00$ & 1.52 & 1.52 & 1.55 \\
\hline \multirow[t]{6}{*}{3} & Manajemen: & & & & \\
\hline & $\begin{array}{l}\text { a. Manajemen Umum (Nilai } \\
\text { Positif) }\end{array}$ & $2.26-3.00$ & 3.00 & 3.00 & 3.00 \\
\hline & b. Kelembagaan (Nilai Positif) & $2.26-3.00$ & 2.00 & 2.00 & 2.00 \\
\hline & $\begin{array}{l}\text { c. Manajemen Permodalan } \\
\text { (Nilai Positif) }\end{array}$ & $2.26-3.00$ & 1.80 & 1.80 & 1.80 \\
\hline & $\begin{array}{l}\text { d. Manajemen Aktiva (Nilai } \\
\text { Positif) }\end{array}$ & $2.26-3.00$ & 2.10 & 2.10 & 2.10 \\
\hline & $\begin{array}{l}\text { e. Manajemen Likuiditas (Nilai } \\
\text { Positif) }\end{array}$ & $2.26-3.00$ & 3.00 & 3.00 & 3.00 \\
\hline \multirow[t]{4}{*}{4} & Efisiensi: & & & & \\
\hline & $\begin{array}{l}\text { a. Rasio Biaya Operasional } \\
\text { Pembiayaan Terhadap } \\
\text { Partisipasi Bruto }\end{array}$ & 4.00 & 2.00 & 2.00 & 2.00 \\
\hline & $\begin{array}{l}\text { b. Rasio Aktiva Tetap terhadap } \\
\text { Total Aset }\end{array}$ & 4.00 & 2.00 & 2.00 & 3.00 \\
\hline & c. Rasio Efisiensi Staf (Orang) & 2.00 & 2.00 & 2.00 & 2.00 \\
\hline \multirow[t]{3}{*}{5} & Likuiditas: & & & & \\
\hline & a. Rasio Kas & 10.00 & 7.50 & 7.50 & 5.00 \\
\hline & $\begin{array}{l}\text { b. Rasio Pembiayaan terhadap } \\
\text { Dana yang Diterima }\end{array}$ & 5.00 & 5.00 & 5.00 & 5.00 \\
\hline \multirow[t]{4}{*}{6} & Kemandirian dan Pertumbuhan: & & & & \\
\hline & a. Rasio Rentabilitas Aset & 3.00 & 0.75 & 0.75 & 0.75 \\
\hline & $\begin{array}{l}\text { b. Rasio Rentabilitas Modal } \\
\text { Sendiri }\end{array}$ & 3.00 & 3.00 & 3.00 & 3.00 \\
\hline & $\begin{array}{l}\text { c. Rasio Kemandirian } \\
\text { Operasional Pelayanan }\end{array}$ & 4.00 & 2.00 & 2.00 & 2.00 \\
\hline \multirow[t]{3}{*}{7} & Jati Diri Koperasi: & & & & \\
\hline & a. Rasio Partisipasi Bruto & 5.00 & 5.00 & 5.00 & 5.00 \\
\hline & $\begin{array}{l}\text { b. Rasio Partisipasi Ekonomi } \\
\text { Anggota }\end{array}$ & 5.00 & 5.00 & 5.00 & 5.00 \\
\hline \multirow[t]{2}{*}{8} & Kepatuhan Prinsip Syariah: & & & & \\
\hline & $\begin{array}{l}\text { a. Pelaksanaan Prinsip-Prinsip } \\
\text { Syariah (Nilai Positif) }\end{array}$ & $7.51-10.00$ & 6.00 & 6.00 & 6.00 \\
\hline \multicolumn{2}{|c|}{$\begin{array}{l}\text { Rekapitulasi Skor Perhitungan } \\
\text { Variabel }\end{array}$} & $81-100$ & 76.17 & 76.17 & 77.20 \\
\hline \multicolumn{2}{|c|}{ Kriteria Komulatif } & Sehat & $\begin{array}{l}\text { Cukup } \\
\text { Sehat }\end{array}$ & $\begin{array}{l}\text { Cukup } \\
\text { Sehat }\end{array}$ & $\begin{array}{l}\text { Cukup } \\
\text { Sehat }\end{array}$ \\
\hline
\end{tabular}


Dari tabel di atas dapat diketahui hasil perhitungan penilaian kesehatan KJKS BMT Binamas dari tahun 2012 sampai tahun 2014 dengan menggunakan delapan variabel yaitu (1) permodalan; (2) kualitas aktiva produktif; (3) manajemen; (4) efisiensi; (5) likuiditas; (6) kemandirian dan pertumbuhan; (7) jati diri koperasi; serta (8) kepatuhan prinsip syariah. Secara umum dapat dilihat bahwa tingkat kesehatan KJKS BMT Binamas secara umum selalu mengalami peningkatan positif di setiap tahunnya, walaupun masih cukup banyak yang perlu diperbaiki.

Pada aspek permodalan menggunakan dua rasio, yaitu rasio modal sendiri terhadap total aset dan rasio kecukupan modal. Dari tabel di atas dapat diketahui bahwa aspek permodalan pada rasio modal sendiri terhadap total modal mendapatkan skor 5.00 di setiap tahunnya, sedangkan pada rasio kecukupan modal selalu mengalami peningkatan yang awalnya mendapatkan skor 2.50 menjadi 5.00 di tahun 2014.

Pada aspek Kualitas Aktiva Produktif menggunakan tiga rasio, dan dari tabel di atas dapat diketahui bahwa pada rasio tingkat piutang dan pembiayaan bermasalah terhadap jumlah piutang dan pembiayaan mendapatkan skor 10.00 di setiap tahunnya, sedangkan pada rasio portofolio terhadap piutang berisiko dan pembiayaan berisiko PAR (Portfolio Asset Risk) mendapatkan skor 5.00 di setiap tahunnya, dan pada rasio Penyisihan Penghapusan Aktiva Produktif (PPAP) terhadap Penyisihan Penghapusan Aktiva Produktif yang Wajib Dibentuk (PPAWD) mengalami sedikit peningkatan yang awalnya mendapatkan skor 1.52 di tahun 2012 kemudian menjadi 1.55 di tahun 2014.

Pada aspek manajemen meliputi beberapa komponen, yaitu manajemen umum, kelembagaan, manajemen permodalan, manajemen aktiva, dan manajemen likuiditas. Secara komulatif aspek manajemen mendapatkan nilai yang cukup baik yaitu mendapatkan skor 11.90 di setiap tahunnya.

Pada aspek efisiensi KJKS didasarkan pada tiga rasio, dan dari tabel di atas dapat diketahui bahwa pada rasio biaya operasional pelayanan terhadap partisipasi bruto mendapatkan skor 2.00 di setiap tahunnya, sedangkan pada rasio aktiva tetap terhadap total modal mendapatkan skor 2.00 di setiap tahunnya tetapi mengalami peningkatan di tahun 2014 yaitu 3.00, dan rasio efisiensi staf mendapatkan skor 2.00 yang juga sama di setiap tahunnya.

Pada aspek likuiditas didasarkan pada rasio kas dan rasio pembiayaan terhadap dana yang diterima. Dari analisis di atas dapat diketahui bahwa pada rasio kas mengalami penurunan yaitu yang awalnya mendapatkan skor 7.50 di tahun 2012 kemudian menjadi 5.00 di tahun 2014. Kemudian untuk rasio pembiayaan terhadap dana yang diterima mendapatkan nilai yang baik yaitu mendapatkan skor 5.00 disetiap tahunnya.

Pada aspek kemandirian dan pertumbuhan didasarkan pada pada rasio rentabilitas aset, rentabilitas modal sendiri (ekuitas), dan kemandirian operasional. Dari tabel di atas dapat diketahui bahwa pada rasio rentabilitas aset mendapatkan nilai yang rendah yaitu mendapatkan skor 0.75 di setiap tahunnya, sedangkan pada rasio rentabilitas ekuitas mendapatkan skor $3.00 \mathrm{di}$ 
setiap tahunnya, dan pada rasio kemandirian operasional pelayanan juga mendapatkan nilai yang rendah yaitu mendapatkan skor 2.00 yang juga sama di setiap tahunnya.

Pada aspek jati diri koperasi didasarkan pada rasio partisipasi bruto dan rasio partisipasi ekonomi anggota. Dari tabel di atas dapat diketahui bahwa pada rasio partisipasi bruto mendapatkan skor 5.00 di setiap tahunnya, sedangkan pada rasio partisipasi ekonomi anggota mendapatkan skor 5.00 di setiap tahunnya. Kemudian pada aspek kepatuhan prinsip syariah dari tabel di atas dapat diketahui bahwa aspek ini mendapatkan skor 6.00 di setiap tahunnya.

Dalam penatapan kriteria tingkat kesehatan KJKS BMT Binamas dapat dikatakan sehat apabila mendapatkan nilai skor rekapitulasi di atas 80 , dan apabila memliki skor kurang dari 50 maka akan dikatagorikan tidak sehat. Dari tabel rekapitulasi hasil perhitungan variabel penilaian kesehatan di atas dapat diketahui bahwa skor rekapitulasi penilaian kesehatan KJKS BMT Binamas pada tahun 2012 sebesar 76.17 sehingga dapat dikategorikan Cukup Sehat, dan pada tahun 2013 mengalami kenaikan menjadi 76.17 dengan kategori Cukup Sehat, selanjutnya pada tahun 2014 sedikit mengalami penurunan menjadi $77.20 \%$ yang masih dalam kategori Cukup Sehat. Nilai rasio yang konsisten diniai tinggi tersebut terjadi karena KJKS terus menjaga kegiatan operasionalnya secara baik.

\section{SIMPULAN}

Berdasarkan hasil analisis penilaian kesehatan KJKS BMT Binamas tahun 2012 sampai tahun 2014 berdasarkan Peraturan Menteri Negara Koperasi Dan UKM Republik Indonesia Nomor: 35.3/Per/M.KUKM/X/2007 tentang pedoman penilaian kesehatan KJKS dan UJKS Koperasi, hasil penelitian dari delapan variabel yang diteliti masing-masing tahun mendapatkan rekapitulasi skor 76.17, 76.17 dan 77.20 yang termasuk dalam kriteria Cukup Sehat

\section{DAFTAR PUSTAKA}

Afandi, P.. (Juli, 2014). Analisis Kinerja Keuangan Untuk Mengukur Kesehatan Keuangan Koperasi Ksu BMT Arafah Kecamatan Bancak Kabupaten Semarang. Among Makarti.Vol. 7 Nomor: 13. Hlm. 25-47.

Buchori, N. S.. (2012, Mei 01) Koperasi Syariah Teori dan Praktek. Banten: Penerbit Pustaka Aufa Media (PAM Pres).

Budiyanto, A. \& Soleh. (2013). Analisis Tingkat Kesehatan Koperasi Kartika Kuwera Jaya Dengan Menggunakan Peraturan Menteri Negara Koperasi Dan Usaha Kecil Dan Menengah Republik Indonesia Nomor: 14/PER/M.KUKM/XII/2009. ESENSI.Vol. 16 Nomor: 1. Hlm. 39-54. 
Hafidz, M., Ismanto, K. \& Rozi, M.. (2011, September 12). Laporan Penelitian Manajemen Risiko BMT (Studi Terhadap Manajemen Risiko BMT-BMT Di Kota Pekalongan). Pekalongan: Sekoiah Tinggi Agama Islam Negeri (STAIN) Pekalongan.

Ismaya, F. R., Susanta, H. \& Rodhiyah.. (2014). Analisis Kesehatan Koperasi Jasa Keuangan Syariah Menggunakan Metode Camel Pada BMT Tamzis Wonosobo. Wonosobo.

Kementerian Negara KUKM RI.. (2014, Desember 31). Rekapitulasi Data Koperasi. November 07, 2015.

http://www.depkop.go.id/index.php?option=com phocadownload \&view=sec

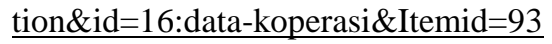

Mudjiyanti, R. \& Rachmawati, E.. (2014, September 6). Analisis Kinerja Keuangan pada Koperasi Syariah di Purwakarta. Prosiding Seminar Hasil Penelitian LPPM UMP 2014. Purwakarta: Universitas Muhammadiyah Purwokwrto. HIm. 86-91.

Netrawati, I G. A. O.. (2013, Maret). Analisis Rasio Return On Equity KPRI Sehat Sejahtra di Propinsi Nusa Tenggara Barat Periode 2009-2011. GaneÇ Swara Vol. 7 Nomor:1. Hlm. 57-62.

Republik Indonesia. (2012). Undang-Undang Republik Indonesia Nomor: 17 Tahun 2012 Tentang Perkoperasian. Jakarta: Sekretariat Negara Republik Indonesia.

Sugiyarso, G.. (2011). Akuntansi Koperasi: Sistem, Metode, dan Analisis Laporan Keuangan. Yogyakarta: PT. Buku Seru.

Suyantomo, S.. (2015, Agustus 24). Personal Interview.

Wardiwiyono, S.. (2012). Internal Control System For Islamic Micro Financing. International Journal of Islamic and Middle Eastern Finance and Management, Vol. 5 Nomor: 4, 340-352. doi: 